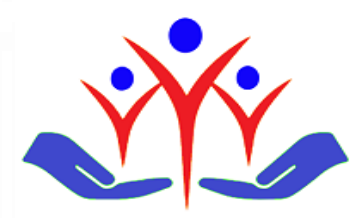

Research Article

\title{
Urinary incontinence frequency and affecting factors in women 18 years and over
}

18 yaş ve üzeri kadınlarda üriner inkontinans sıklığı ve etkileyen faktörler

\author{
(D) Kubra Yildirima ${ }^{\mathbf{a}}$ (D) Ege Agirman ${ }^{\mathbf{b}}$, (D) Secil Arica ${ }^{\mathbf{c}}$

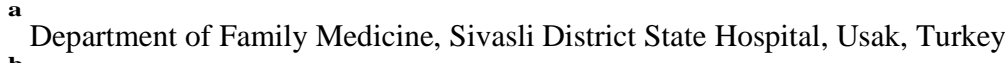 \\ Department of Family Medicine, Cameli District State Hospital, Denizli, Turkey \\ Department of Family Medicine, Okmeydani Training and Research Hospital, University of Health Sciences, Istanbul, Turkey
}

\begin{abstract}
Introduction: Urinary incontinence(UI) is a complicated condition that affects women of all ages, is common, affects life negatively, and occurs for many reasons. It does not only have a medical problem for women but also affects the quality of life defined as physical, psychological, economic and social well-being. In our study, it was aimed to evaluate the frequency of urinary incontinence and the affecting factors in women aged 18 and over.

Methods: 212 female patients aged between 18-85 who applied to Cemil Tascioglu City Hospital Family Medicine Polyclinics were included in this study. Those patients were divided into two groups: urinary incontinent and continent. General poll form, ICIQ-SF were interrogated. In general poll form, medical story about demographic data, personal history, family history, additional diseases, UI risk factors was interrogated. Dates of study were evaluated in the sense of meaningfulness by Shapiro Wilk test, Mann Whitney U test, Pearson Ki-Kare test, Fisher's Exact Ki-Kare test.

Results: Number of incontinent and continent cases was 111 and 101, respectively. So, the frequency of UI was found to be 52.4\%. Average age of incontinent and continent cases was $51.07 \pm 11.80$ and $43.50 \pm 12.80$ respectively. $37.7 \%$ of UI cases had urgent-type, $12.3 \%$ of UI cases had stress-type and 30.2\% had mixed-type UI. Increase in body mass index ( $\mathrm{p}<0.001)$, low level of education $(\mathrm{p}<0.001)$, curettage (p:0.014), menopause ( $\mathrm{p}<0.001$ ), giving birth to relatively big babies (p:0.048), hypertension (p:0.001), diabetes mellitus (p:0.038), constipation (p:0.042), genital prolapsus (p:0.008) were meaningfully higher in the incontinent group.

Conclusion: In our study; it was found that urinary incontinence rate increased with increasing age. The vast majority of women see this as a result of being a woman and aging and they do not consult a doctor. In our study, we found that $86.8 \%$ of women with urinary incontinence did not consult a doctor. Most of the individuals with urinary incontinence can be recognized and treated effectively by their family physicians in primary care. Therefore, family physicians should identify the problem of urinary incontinence in patients who apply to outpatient clinics, identify risk factors, define and treat them.
\end{abstract}

Keywords: Urinary incontinence, urinary frequency, female

\section{$\ddot{O} \mathbf{z}$}

Giriş: Üriner inkontinans(UI) her yașta kadını etkileyen, yaygın görülen, yaşamı olumsuz yönde etkileyen, birçok nedenden dolayı meydana gelen karışık bir durumdur. Kadınların sadece tıbbi sorunu olmayıp aynı zamanda fiziksel, psikolojik, ekonomik ve sosyal iyilik hali olarak tanımlanan yaşam kalitesini de etkilemektedir. Çalışmamızda 18 yaş ve üzeri kadınlarda üriner inkontinans sıklığı ve etkileyen faktörlerin değerlendirilmesi amaçlanmıştır.

Yöntem: Bu çalışmaya Cemil Taş̧̧ıŏlu Şehir Hastanesi Aile Hekimliği Polikliniklerine başvuran, yaşları 18-85 arasında değişen 212 kadın hasta dahil edildi. Bu hastalar idrar kaçıran ve kaçırmayan olmak üzere iki gruba ayrılarak, katılımcılara ICIQ-SF (International Consultation on Incontinence Questionnaire Short Form) anket formu uygulandı. Anket formunda demografik bulgular, özgeçmiş, soy geçmiş, ek hastalıklar, idrar kaçırma risk faktörleri ile ilgili anamnez bilgileri sorgulandı. Çalışmada elde edilen bulgular, bağımsız gruplar t testi, Shapiro Wilk testi, Mann Whitney U testi, Pearson Ki-Kare testi, Fisher's Exact Ki-Kare testi ile istatiksel anlamlılık açısından değerlendirildi.

Bulgular: Katılımcılardan idrar kaçıran olguların sayısı 111 ve idrar kaçırmayan olguların sayısı 101 olup, üriner inkontinans sıklığı $\% 52,4$ saptandı. İdrar kaçıran

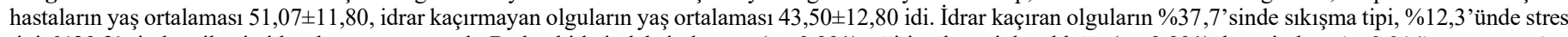
tipi, \%30,2' sinde miks tip idrar kaçırma saptandı. Beden kitle indeksinde artış $(\mathrm{p}<0,001)$, eğitim düzeyi düşüklüğ̈̈ ( $<<0,001)$, kürtaj olma (p: 0,014$)$, menopoz (p< 0,001),iri bebek doğurma (p: 0,048), hipertansiyon (p: 0,01), diyabetes mellitus (p: 0,038), kabızlık (p: 0,042), genital prolapsus (p: 0,008) idrar kaçıran grupta anlamlı olarak fazlaydı.

Sonuç: Çalışmamızda yaş ilerledikçe idrar kaçırma oranının arttığı saptanmıştır. Kadınların büyük çoğunluğu üriner inkontinansı kadın olmanın ve yaşlanmanın bir sonucu olarak görmekte ve doktora başvurmamaktadır. Çalışmamızda üriner inkontinansı olan kadınların \%86,8'inin doktora başvurmadığı saptanmıştır. Üriner inkontinanslı bireylerin çoğu birinci basamaktaki aile hekimleri tarafindan tanınabilir ve etkili bir şekilde tedavi edilebilir. Bu sebeple aile hekimleri polikliniklere başvuran hastalarda idrar kaçırma problemini tespit etmeli, risk faktörlerini belirlemeli, tanımlamalı ve tedavi etmelidir.

Anahtar kelimeler: üriner inkontinans, idrar siklığı, kadın

\begin{tabular}{|c|c|c|c|c|}
\hline Received & Accepted & Published Online & Corresponding Author & E-mail \\
\hline August 13, 2020 & January 7, 2021 & April 3, 2021 & Ege Agirman, MD & egeozince @ hotmail.com \\
\hline Correspondence & \multicolumn{2}{|c|}{ Dr. Ege Ağırman, Yeni Mah. Menekşe Sok. Güler Can Apt. No:27/5 Çameli/Denizli, Turkey } \\
\hline
\end{tabular}




\section{Introduction}

Urinary incontinence(UI) is defined informally as involuntary leakage of urine. Urinary incontinence; in the terminology standardization report of the International Continence Association; it is an objectively demonstrable involuntary urinary incontinence that causes social or hygienic problems [1]. Many people experience occasional, minor leaks of urine. Others may lose small to moderate amounts of urine more frequently. Although urinary incontinence is not a life-threatening problem, it is a condition that negatively affects the quality of life of a woman of any age.

Urinary incontinence is a common and often embarrassing problem. The severity ranges from occasionally leaking urine when you cough or sneeze to having an urge to urinate that's so sudden and strong you don't get to a toilet in time. Also, the feeling of discomfort caused by constant wetness, irritation, and odor causes various mental problems in women, negatively affects daily home and work life, sexual life and restricts their social life. Although the prevalence of UI increases with age, it should not be accepted as the natural course of old age [2-4].

In this study, we aimed to make determinations about urinary incontinence, which causes such discomfort in daily life, especially for women. In this study, the frequency and types of urinary incontinence, risk factors, susceptibility conditions, its relationship with chronic diseases, and its relationship with the birth history in women will be examined. Therefore, aim of this study is to investigate the frequency of UI and the influencing factors in women aged 18 and over.

\section{Methods}

This is a descriptive study conducted to determine the frequency of UI and the factors affecting it in women aged 18 and over who apply to Family Medicine Polyclinics within Prof. Dr. Cemil Taşçığlu City Hospital. The universe of the research is 18-85 age group female patient, who applied to the Family Practice Outpatient Clinics between 01.02.2017 and 01.04.2017 and who voluntarily agreed to participate in the study. It was selected by taking the consent form from women aged 18 and over who agreed to participate in the research. The pediatric patient group under the age of 18, male patients and patients who did not volunteer to participate were not included in our study.

ICIQ-SF (International Consultation on Incontinence Questionnaire Short Form) questionnaire was applied to the participants. The ICIQ-SF is a questionnaire for evaluating the frequency, severity and impact on quality of life (QoL) of urinary incontinence in men and women in research and clinical practice across the world. In the questionnaire, anamnesis information about demographic findings, medical history, family history, additional diseases, urinary incontinence risk factors were questioned.

ICIQ-SF was recommended by the International Incontinence Consultation held in 2004 [5]. And also, the Turkish validity and reliability study of the ICIQ-SF test was conducted by Kara CK in 2014 [6]. In primary care practices, it is an important form in determining the type of urinary incontinence. Family physicians can easily monitor the appropriateness and response of patients to treatment using this. The decrease in the ICIQSF score calculated at the time of admission with appropriate treatment of the patient or the complete end of urinary incontinence shows that the primary care physician takes an approach in accordance with international standards for urinary incontinence problem.

This study was found ethically appropriate by the Istanbul Okmeydani Training and Research Hospital Clinical Research Ethics Committee according to its decision dated 17.01.2017 and numbered 584 .

NCSS (Number Cruncher Statistical System) 2007 (Kaysville, Utah, USA) program was used for statistical analysis. While evaluating the study data, descriptive statistical methods (mean, standard deviation, median, first quarter, third quarter, frequency, percentage, minimum, maximum) as well as the suitability of quantitative data to normal distribution were tested by Shapiro-Wilk test and graphical examinations. Independent groups $t$ test was used for the comparison of the quantitative variables with normal distribution, and Mann-Whitney $U$ test was used for the comparison of the quantitative variables with no normal distribution between the two groups. Pearson chi-square test and Fisher's exact test were used to compare qualitative data. $\mathrm{p}<0.05$ was considered statistically significant.

\section{Results}

Participants; it was examined under two groups as 'urinary incontinence' $(n=111)$ and without urinary incontinence $(n=101)$. The ages of the cases vary between 21 and 85 years and the average age is $47.46 \pm 12.83$ years. The lengths of the patients ranged between 145 and $175 \mathrm{~cm}$, with an average of $159.08 \pm 5.61$. The weights of the cases ranged from 47 to $120 \mathrm{~kg}$, with an average of $74.32 \pm 13.66 \mathrm{kilograms}$. BMI values range from 18.8 to $48.9 \mathrm{~kg} / \mathrm{m}^{2}$, with an average of $29.42 \pm 5.42 \mathrm{~kg} / \mathrm{m}^{2}$.

$76.9 \%(\mathrm{n}=163)$ of the cases are married, $8.5 \%(\mathrm{n}=18)$ are single, $14.6 \%(\mathrm{n}=31)$ are widows. $9.4 \%(\mathrm{n}=20)$ of the cases are not literate, $11.8 \%$ $(\mathrm{n}=25)$ are literate, $46.7 \%(\mathrm{n}=99)$ are primary school graduates, $32.1 \%(\mathrm{n}=68)$ are secondary school and above graduate. While gravidity numbers range from 0 to 12 with an average of $3.29 \pm 2.14$, the number of parity varies between 0 and 10 and the average is $2.48 \pm 1.52$, the number of abortion varies between 0 and 5 , with an average of $0.38 \pm 0.78$, the number of curettage varies between 0 and 7 , with an average of $0.43 \pm 0.96$.

It was determined that $50 \%$ of the cases $(n=106)$ entered menopause. While the first birth age of $36.2 \%(n=68)$ of cases giving birth is under 20 years old, $52.1 \%(\mathrm{n}=98)$ is between $20-25$ years old and $11.7 \%(\mathrm{n}=22)$ is over 25 years old. While $15.4 \%(\mathrm{n}=29)$ of the cases giving birth are under 25 as the last birth age, $29.8 \%(n=56)$ are between $25-29$ years old, $29.8 \%(n=56)$ are between $30-34$ years old and $25 \%(n=47)$ is over 35 years old. It was found that $31.9 \%(n=60)$ of the cases giving birth had a delivery action longer than 24 hours. 
Episiotomy was detected in $60.1 \%(\mathrm{n}=113)$ of cases giving birth. It was found that $27.1 \%(\mathrm{n}=51)$ of the cases giving birth had a history of giving birth to a baby over $4 \mathrm{~kg}$. It was determined that $28.2 \%(\mathrm{n}=53)$ of cases giving birth had a history of cesarean delivery.

Table 1. Distribution of data on disease and symptoms

\begin{tabular}{llll}
\hline \multirow{2}{*}{ Symptom duration (as a year) } & & Min-Max & Mean $\pm \mathbf{s d}$ \\
\cline { 2 - 3 } A history of frequent urinary tract infections & & $0.3-40$ & $4.89 \pm 5.79$ \\
& & $\mathbf{n}$ & $\mathbf{\%}$ \\
\cline { 2 - 3 } A history of genital prolapses & Yes & 89 & 42 \\
& No & 123 & 58 \\
Constipation & Yes & 31 & 14.6 \\
& No & 181 & 85.4 \\
A history of vaginal surgery & Available & 110 & 51.9 \\
& Absent & 102 & 48.1 \\
Receiving hormone replacement therapy & Yes & 33 & 15.6 \\
& No & 179 & 84.4 \\
A history of chronic illness & Yes & 34 & 16 \\
& No & 84 \\
& Hypertension & 71 & 33.5 \\
& Diabetes M & 42 & 19.8 \\
Diuretic use history & COPD & 11 & 5.2 \\
& Hypothyroidism & 37 & 17.5 \\
A history of urinary incontinence & Other & 65 & 30.7 \\
History of urinary incontinence in childhood & Available & 7 & 3.3 \\
& Absent & 205 & 96.7 \\
& Available & 111 & 52.4 \\
\hline
\end{tabular}

It was determined that $52.4 \%(\mathrm{n}=111)$ of the cases had a history of urinary incontinence, and $47.6 \%(\mathrm{n}=101)$ never had urinary incontinence, $9.4 \%(n=20) 1$ or less times a week, $12.3 \%(n=26) 2$ or 3 times a week, like $7.5 \%(n=16)$ once a day, $22.2 \%(n=47)$ several times a day, and $0.9 \%(\mathrm{n}=2)$ every time has been found to be missing.

While $47.6 \%(n=101)$ of the participants thought that no urinary incontinence, $31.1 \%(n=66)$ were small, $17.9 \%(n=38)$ were moderate, $3.3 \%$ $(n=7)$ were very was found to think that he had missed a lot of urine. VAS (Visual Analog Scale) scores range from 0 to 10, with an average of $2.78 \pm 3.53$. In our study, when the responses of women with urinary incontinence to the VAS used to evaluate the quality of life in ICIQ-SF were evaluated, the mean VAS score of the group was $2.78 \pm 3.53$, and the mean ICIQ-SF score was $11.10 \pm 4.83$.

Considering urinary incontinence types, 37.7\% $(\mathrm{n}=80)$ compression type, $12.3 \%(\mathrm{n}=26)$ stress type, and $30.2 \%(\mathrm{n}=64)$ mixed type urinary incontinence. It was determined that $13.2 \%(\mathrm{n}=28)$ of the cases went to the doctor due to urinary incontinence. It was found that $53.6 \%(\mathrm{n}=15)$ of the patients who went to the doctor for urinary incontinence recommended lifestyle changes, $21.4 \%(\mathrm{n}=6)$ behavioral treatment and $60.7 \%(\mathrm{n}$ =17) recommended medical treatment.

The ages of the patients with urinary incontinence were found to be statistically significantly higher than those of the patients without urinary incontinence ( $\mathrm{p}<0.001$ ). There was no statistically significant difference between the groups in terms of height ( $p>0.05)$. It was determined that the weight values of the patients who missed urine were statistically significantly higher than those of the patients who did not pass urine (p $<0.001$ ). It was found that BMI values of the patients who missed urine were statistically significantly higher than the values of those who did not pass urine $(\mathrm{p}<0.001)$.

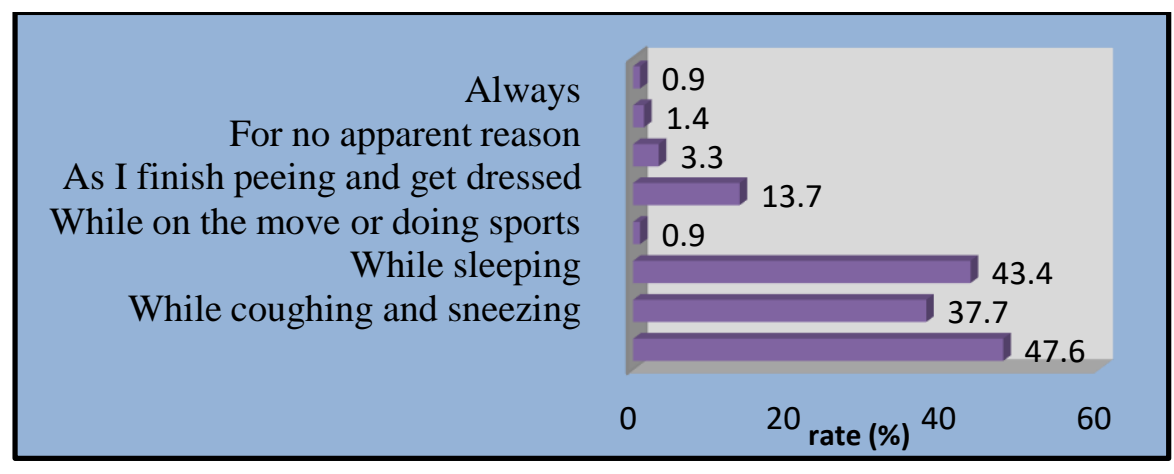

Figure 1. The condition at the time of urinary incontinence

There was a statistically significant difference in terms of urinary incontinence according to the marital status of the cases (p: 0.003). As a result of the bilateral evaluations performed using Bonferroni correction, the rate of urinary incontinence in married cases was found to be statistically significantly higher than in single cases (p: 0.003). 
There was a statistically significant difference in the rate of urinary incontinence according to the educational status of the cases ( $\mathrm{p}<0.001$ ). As a result of bilateral evaluations using Bonferroni correction, the rate of urinary incontinence was found to be statistically significantly higher in illiterate patients than in literate and secondary school graduates (p: 0.004, p: 0.015 , respectively). The rate of urinary incontinence was found to be statistically significantly higher in primary school graduate cases than in literate and secondary school graduates $(\mathrm{p}<0.001, \mathrm{p}<0.001$, respectively).

It was found that the gravidity values of the patients who missed the urine were statistically significantly higher than the values of the patients who did not pass urine (p: 0.001). The parity values of the patients who missed urine were found to be statistically significantly higher than the values of the patients who did not pass urine (p: 0.001). There was no statistically significant difference between the groups in terms of abortion values ( $p>0.05$ ). It was found that the curettage values of the patients who missed the urine were statistically significantly higher than the values of the patients who did not pass urine (p: 0.014).

The rate of urinary incontinence was found to be statistically significantly higher in patients who have entered the menopause than those who have not been in the menopause $(\mathrm{p}<0.001)$.

In cases that gave birth; there was no statistically significant difference in terms of urinary incontinence compared to the age of first and last birth $(\mathrm{p}>0.05)$.

In cases that gave birth; there was no statistically significant difference in terms of urinary incontinence rates according to the condition of giving birth longer than 24 hours ( $>0.05$ ), there was no statistically significant difference in terms of urinary incontinence rates when episiotomy was opened ( $p>0.05$ ), The rate of urinary incontinence was found to be statistically significantly higher in patients who gave birth to babies over 4 kilograms than those who did not deliver babies over 4 kilograms (p: 0.048), There was no statistically significant difference in terms of urinary incontinence rates according to the presence of cesarean history ( $p>0.05$ ).

According to the history of frequent urinary tract infections, no statistically significant difference was found in terms of urinary incontinence rates $(\mathrm{p}>0.05)$.

The rate of urinary incontinence was found to be statistically significantly higher in patients with a history of genital prolapse than those without a history of genital prolapse (p: 0.008). Urinary incontinence rate was found to be statistically significantly higher in cases with constipation than in cases without constipation (p: 0.042).

There was no statistically significant difference in terms of urinary incontinence rates according to the history of vaginal operation and hormone replacement therapy ( $p>0.05)$. In cases where hypertension was observed, urinary incontinence rate was found to be statistically significantly higher than in cases without HT (p: 0.010). Urinary incontinence rate was found to be statistically significantly higher in patients with diabetes mellitus than those without diabetes (p: 0.038). There was no statistically significant difference in terms of urinary incontinence compared to the presence of COPD ( $p>0.05$ ). The rate of urinary incontinence was found to be statistically significantly lower in patients with hypothyroidism than those without hypothyroidism (p: 0.008). There was no statistically significant difference in terms of urinary incontinence compared to the presence of other chronic diseases ( $p>0.05$ ). There was no statistically significant difference in terms of urinary incontinence according to the diuretic use history $(p>0.05)$. There was no statistically significant difference in childhood incontinence rates according to urinary incontinence $(\mathrm{p}>0.05)$.

\section{Discussion}

Urinary incontinence is a common condition that affects the life of women at any age and occurs for many reasons. It affects not only the medical problems of women but also the quality of life, which is defined as physical, psychological, economic and social well-being [7].

Urinary incontinence risk factors are classified under two titles, which can be changed and cannot be changed. Factors that cannot be changed; female gender, older age, white race, gynecological surgery, prolapse, heredity, number of pregnancies, birth, difficult birth history, excessive number of births, large baby history, menopause, childhood urinary incontinence history, chronic disease, changeable risk factors ; weight, urinary tract infection, constipation, diuretic use, respiratory problems, diabetes, caffeinated beverages and tea consumption, smoking, poor health, working conditions and night wakefulness are included [8-12].

In our study, which are the most discussed among the risk factors that can be changed and cannot be changed; age, marital status, educational status, body mass index, number of pregnancies, menopause, age of first and last birth, difficult birth, history of large baby birth, constipation, urinary tract infection, vaginal a history of surgery, chronic illness and medication, and childhood urinary incontinence were examined.

In our study, the ages of the patients ranged from 21 to 85 years, with an average of $47.46 \pm 12.83$ years. It was found that urinary incontinence rate increased with increasing age. As in some studies, the frequency of UI increases with age in our study [9]. Many women regard this as a result of old age, rather than seeing it as a disease. With aging, there is a decrease in bladder capacity, urinary flow rate and ability to urinate. Neurological, urological, renal problems, decreased mobility, medication use, estrogen deficiency, diabetes and urinary tract infections also lead to urinary incontinence development $[8,9]$. 
In the study; frequency of urinary incontinence; $45.9 \%$ of those who missed less than once a week, $17.4 \%$ two or three times a week, $9.9 \%$ who missed once a day, $13.2 \%$ who missed a few times a day, and $13.6 \%$ of those who always incontinence was detected [9]. Urinary incontinence severity; It was determined that $79.8 \%$ of them were mild, $15.7 \%$ were moderate, and $4.5 \%$ were severe [9]. In our study, it was determined that $9.4 \%$ of those who discontinued once a week or less frequently, $12.3 \%$ two or three times a week, $7.5 \%$ who missed once a day, $22.2 \%$ who missed a few times a day, and $0.9 \%$ always had urinary incontinence. It was determined that the severity of urinary incontinence was $31.1 \%$ in small amount, $17.9 \%$ in moderate and $3.3 \%$ in large amount.

When we look at UI types; in the study conducted by Hunskaar et al. in 17080 women between the ages of 18-99 in four European countries, the prevalence of urinary incontinence was 35\%, the prevalence of stress-compression-mixed urinary incontinence was 37\%, 20\% -33\% and other types of urinary incontinence, respectively. It was found that stress urinary incontinence was more common in the middle age group, and the prevalence of compression and mixed urinary incontinence increased in the older ages [12].

The prevalence according to UI types in domestic and international studies; respectively; stress has a wide range of 15.4-41.2\%, compression 9.8$39.8 \%$ and mixed type incontinence $24.2-70.1 \%$ [11-13]. It is reported that this wide range of distribution results from the different definition of urinary incontinence in the studies conducted, the difference of the study regions and the methods used, and the inclusion of very old individuals also contributed to this difference.

In our study we found that urinary incontinence was $52.4 \%$, urge incontinence was $37.7 \%$, stress-type urinary incontinence was $12.3 \%$, mixed type urinary incontinence was $30.2 \%$.

When we look at the relationship between UI and educational status; in the study conducted by Akgun, UI was found with a high rate of $88.5 \%$ in women with primary education and lower education [13], in the study conducted by Akkus, it was found that as the education level increases, the frequency of incontinence decreases [14]. This may be due to the fact that the data collected are based on the statements of the patients, and patients with a high level of education can't give sufficient information and contribution due to their reservations such as harming their status in the society, being exposed to prejudiced behaviors of the society.

In our study, a statistically significant difference was found in terms of UI rate according to the education status of the cases. It was found that the rate of UI in the primary school graduates was statistically significantly higher than the literate and middle school and above graduates.

In the literature, there are studies supporting relationship between hypertension and urinary incontinence [13,15]. Kocak et al. think that the relationship between hypertension and UI may be due to chronic drug use in the hypertension group [9]. Diuretics used in the treatment of hypertension may cause UI by causing polyuria, urgency, frequent urination, and alpha blockers by causing urethral relaxation. In our study, in cases with hypertension, the rate of UI was found to be significantly higher than in cases without hypertension. It was determined that the rate of UI was statistically significantly higher in patients with diabetes mellitus than in patients without DM.

When we look at the relation of body mass index and UI; in some studies, it was found that UI is more common in women with high body mass index [15-18]. Kocak et al., in their study conducted on 1012 women aged 18-92, stated that 31.3\% of women with urinary incontinence had a body mass index above 25 and $14.5 \%$ had a body mass index below 25 [9]. In our study, the rate of urinary incontinence was found to be significantly higher in patients with a body mass index of 25 and above.

Also, in our study, similar to the other study; we found that menopause is an important risk factor for UI [19]. Estrogen decreases in advanced age results in disruption in urination habit and urinary incontinence [19]. So, the hormone profile can be reviewed in women with UI at a young age. However, no relationship was found between estrogen replacement and UI.

In addition, it was found in our study that the rate of urinary incontinence $(59.1 \%)$ in cases with constipation was statistically significantly higher than in cases without constipation. Chronic constipation causes tension in the pudendal nerve and may lead to impairment in pelvic muscle function, and constipation causes pressure on the bladder and increases the risk of urinary incontinence $[7,20]$.

In a study, conducted to determine the relationship between UI and sexual activity, although greater amounts of urine loss, stress incontinence, and nocturnal incontinence were independently associated with sexual activity, it was found that frequency of UI was not related to being sexually active [21]. In our study it was found that the rate of UI (57.7\%) in married or sexually active cases was statistically significantly higher than in single cases.

When we look at the relation of birth history and UI; in our study, the rate of urinary incontinence (63.2\%) was found to be significantly higher in those whose first birth age was less than 20 years old. In our country, the lower birth age in women with low education level effects in increasing the rate of urinary incontinence [20]. Urinary incontinence has been reported less in women who have never given birth than in women who have given birth [22]. Vaginal delivery damages the pelvic facial support and results in partial denervation of the pelvic floor and urethral muscles. With vaginal delivery, functional urethral length, urethral closing pressure and maximum urethral pressure decrease.

Some studies report that; episiotomy increased the risk of stress type UI [15,17]. Some studies have shown that obstetric traumas such as prolonged labor, episiotomy opening, vaginal delivery, and large baby birth play a role in urinary incontinence [22-24]. In the study conducted by Eason et al., they reported that vaginal delivery increased the rates of UI and that opening episiotomy did not cause an additional increase in UI [25]. 
When compared with vaginal delivery, cesarean delivery decreases the risk of UI [23-26]. In our study, it was found that the gravidity and parity values were statistically significantly higher than the values of cases without UI. It was found that the values of cases with episiotomy (60.2\%), a history of giving birth to a large baby $(68.6 \%)$, and a history of difficult birth $(51.7 \%)$ were significantly higher in UI. There was no statistically significant difference in urinary incontinence rates according to the presence of cesarean section history. No statistically significant difference was found between the groups with and without incontinence in terms of abortion values.

Even if it does not result in birth, pregnancy changes the hormonal balance, creates relaxation in the pelvic muscles and ligaments and increases the rate of UI. Therefore, having an abortion increases the risk of urinary incontinence. In our study, it was found that the values of those who underwent abortion were statistically significantly higher than the values of cases without UI.

In our study, no statistically significant difference was found in terms of urinary incontinence rates according to the history of vaginal operation. It was found that the rate of urinary incontinence $(74.2 \%)$ in cases with a history of genital prolapse was statistically significantly higher than in cases without a history of genital prolapse.

Urinary tract infection is a temporary condition that causes urinary incontinence. In a study conducted by Kocak et al., recurrent urinary tract infection increased the risk of urinary incontinence 2 times [9]. In our study, no statistically significant difference was found in terms of urinary incontinence rates according to the history of frequent urinary tract infections.

In the study, conducted by Koçak et al. an unexplained relationship was found between childhood UI and adult UI [9]. In our study, no statistically significant difference was found in terms of UI rates according to the history of urinary incontinence in childhood.

\section{Limitations}

The limitation of our study; since the data collected are based on the statements of the patients and are relative, it is that individuals at different sociocultural levels may give different answers. In addition, another limitation of our study is that it has a margin of error due to the verbal acquisition of patients' height and weight data.

\section{Conclusion}

As a result, it was found that urinary incontinence rate increased with increasing age. In our study, we found that urinary incontinence was $52.4 \%$, urge incontinence was $37.7 \%$, stress-type urinary incontinence was $12.3 \%$, mixed type urinary incontinence was $30.2 \%$.

Urinary incontinence was found to be higher in married women than in single women, in women who have given birth than women who have never given birth, in women who had a vaginal delivery than women who had a cesarean delivery, in postmenopausal women than in premenopausal women. In addition, UI was found to be higher in women with a body mass index of 25 and above than women with a low body mass index, in women with lower education levels than women with higher education levels.

Urinary incontinence has long been ignored by patients and physicians. The vast majority of women see this as a result of being a woman and aging and they do not consult a doctor[8]. In our study, we found that $86.8 \%$ of women with urinary incontinence did not consult a doctor. Most of the individuals with urinary incontinence can be recognized and treated effectively by their family physicians in primary care. Therefore, family physicians should identify the problem of urinary incontinence in patients who apply to outpatient clinics, identify risk factors, define and treat them.

\section{Conflict of interest: None.}

Financial support: None

\begin{tabular}{|l|r|l|}
\hline \multicolumn{2}{|c|}{ Author Contributions } & Author Initials \\
\hline SCD & Study Conception and Design & KY, SA \\
\hline AD & Acquisition of Data & KY,SA \\
\hline AID & Analysis and Interpretation of Data & EA, \\
\hline DM & Drafting of Manuscript & KY, EA, \\
\hline CR & Critical Revision & KY, EA, SA \\
\hline
\end{tabular}

\section{References}

1. Abrams P, Cardozo L, Fall M, Griffiths D, Rosier P, Ulmsten U, et al. The standardisation of terminology in lower urinary tract function: report from the standardisation sub-committee of the International Continence Society. Urology 2003;61(1):37-49 https://doi.org/10.1016/s0090-4295(02)02243-4

2. Araki I, Beppu M, Kajiwara M, Mikami Y, Zakoji H, Fukasawa M, et al. Prevalence and impact on generic quality of life of urinary incontinence in Japanese working women: assessment by ICI questionnaire and SF-36 Health Survey. Urology 2005;66(1):88-93 https://doi.org/10.1016/j.urology.2005.01.059

3. Basak T, Kok G, Guvenc G. Prevalence, risk factors and quality of life in Turkish women with urinary incontinence: a synthesis of the literatüre. Int Nurs Rev 2013;60(4):448-60 https://doi.org/10.1111/inr.12048

4. Yalcin O. [Basic Gynecology and Obstetrics Information. Urogynecology] (in Turkish). Gunes Medical Bookstore, Ankara 
2008;(2):730-47

5. Temll C, Haidinger G, Schmidbauer J, Schatzl G, Madersbacher S. Urinary incontinence in both sexes: Prevelance rates and impact on quality of life and sexual life. Neurourol Urodyn 2000;19:259-71 https://doi.org/10.1002/(sici)1520-6777(2000)19:3\%3C259::aidnau7\%3E3.0.co;2-u

6. Kara CK. Karakaya IÇ, Tunali N, Karakaya MG. Reliability and validity of the Incontinence Quiz-Turkish version. J Obstet Gynaecol Res. 2018;44(1):144-50. https://doi.org/10.1111/jog.13469

7. Saboia DM, Firmiano ML, Bezerra K, Neto JA, Oria MO, Vasconcelos CT, et al. Impact of urinary incontinence types on women's quality of life. Rev Esc Enferm USP 2017;21;51:e03266. https://doi.org/10.1590/s1980-220x2016032603266

8. MacDiarmid S, Rosenberg M. Overactive bladder in women; symptom impact and treatment expectations. Curr Med Res Opin 2005; 21: 1413-21 https://doi.org/10.1185/030079905X59076

9. Kocak İ, Okyay P, Dundar M, Erol H, Beser E. Female urinary incontinence in the west Turkey: Prevalence, risk factors and impact on the quality of life. Eur Urol, 2005;48(4):634-41. https://doi.org/10.1016/j.eururo.2005.04.017

10. Cetinel B, Demirkesen O, Tarcan T, Yalcin O, Kocak T, Senocak M, et al. Hidden female urinary incontinence in urology and obstetrics and gynecology outpatient clinics in Turkey: What are the determinants of bothersome urinary incontinence and help-seeking behavior? Int Urogynecol J Pelvic Floor Dysfunct, 2007; 18(6):659-64. https://doi.org/10.1007/s00192-006-0223-6

11. Alves JO, Luz ST, Brandao S, Luz CM, Jorge RN, Roza TD, et al. Urinary incontinence in physically active young women: prevalence and related factors. Int J Sports Med 2017;38(12):937-941. https://doi.org/10.1055/s-0043-115736

12. Hunskarr S, Lose J, Sykess D, Voss S. The prevelance of urinary incontinence in women in four European countries. BJU Int 2004;93(3):324-30. https://doi.org/10.1111/j.1464-410x.2003.04609.x

13. Akgun G, Sut N, Kaplan P. Prevalance of the urinary incontinence in women older than 40 years and influence of their QoL. Turkiye Klinikleri J Gynecol Obst. 2010;20(6):378-86.

14. Akkus Y, Pinar G. Evaluation of the prevalence, type, severity, and risk factors of urinary incontinence and its impact on quality of life among women in Turkey. Int Urogynecol J. 2016;27(6):887-93. https://doi.org/10.1007/s00192-015-2904-5

15. Hsieh CH, Lee MS, Lee MC, Kuo TC, Hsu CS, Chang ST, et al. Risk factors for urinary incontinence in Taiwanese women aged 20-59 years. Taiwan J Obstet Gynecol 2008;47(2):197-202 https://doi.org/10.1016/s1028-4559(08)60080-7

16. Nygaard CC, Schreiner L, Morsch TP, Saadi RP, Figueiredo MF, Padoin AV. Urinary Incontinence and Quality of Life in Female Patients with Obesity. Rev Bras Ginecol Obstet. 2018;40(9):534-539 https://doi.org/10.1055/s-0038-1670626

17. Zhu L, Lang JH, Wang H, Han SM, Liu CY. the study on the prevalence and associated risk factors of female urinary incontinence in Beijing women. Zhonghua Yi Xue Za Zhi 2006,86(11):728-31 https://pubmed.ncbi.nlm.nih.gov/16681943/

18. Subak LL, Richter HE, Hunskaar S. Obesity and urinary incontinence: epidemiology and clinical research update. J Urol. 2009;182(6 Suppl):S2-7. https://doi.org/10.1016/j.juro.2009.08.071

19. Singh U, Agarwal P, Verma ML, Dalela D, Singh N, Shankhwar P. Prevalence and risk factors of urinary incontinence in Indian women: A hospital-based survey. Indian J Urol 2013;29(1): 31-36. https://dx.doi.org/10.4103\%2F0970-1591.109981

20. [Turkey Population and Health Survey 2010] (in Turkish). Available at: http://www.hips.hacettepe.edu.tr/tnsa2008/data/TNSA2008_ana_Rapor-tr.pdf

21. Tannenbaum C, Corcos J, Assalian P. The relationship between sexual activity and urinary incontinence in older women. $\mathrm{J}$ Am Geriatr Soc. 2006;54(8):1220-4. https://doi.org/10.1111/j.1532-5415.2006.00827.x

22. Geelen HV, Ostergard D, Sand P. A review of the impact of pregnancy and childbirth on pelvic floor function as assessed by objective measurement techniques. Int Urogynecol J 2018; 29(3):327-38 https://doi.org/10.1007/s00192-017-3540-Z

23. Yang X, Zheng H, Liao Q, Tao R, Fu C, Peng X, et al. Mode of delivery on urinary incontinence. Zhonghua Fu Chan Ke Za Zhi [Article in Chinese] 2004;39(10):662-5 https://pubmed.ncbi.nlm.nih.gov/16144561/

24. Eason E, Labrecque M, Marcoux S, Mondor M: Effects of carrying a pregnancy and of method of delivery on urinary incontinence: a prospective cohort study. BMC Pregnancy Childbirth 2004;(4):4 https://doi.org/10.1186/1471-2393-4-4

25. Luo D, Chen L, Yu X, Ma L, Chen W, Zhou N, et al. Differences in urinary incontinence symptoms and pelvic floor structure changes during pregnancy between nulliparous and multiparous women. Peer J 2017;(5): 3615. https://dx.doi.org/10.7717\%2Fpeerj.3615

26. Demaagd GA, Davenport TC. Management of urinary incontinence. J Clin Pharm Ther 2012;37(6): 345-61 https://www.ncbi.nlm.nih.gov/pmc/articles/PMC3411204/ 